\title{
Salvage Robotic-Assisted Seminal Vesiculectomy for Merkel Cell Carcinoma Metastasis
}

\section{Vesiculectomia Seminal Robótica de Salvação em Metástase de Carcinoma de Células de Merkel}

\author{
Luísa Jerónimo ALVES $\triangle^{1}$, Bruno GRAÇA², Kris MAES ${ }^{2}$ \\ Acta Med Port 2022 Jun;35(6):488-491 - https://doi.org/10.20344/amp.15925
}

\section{ABSTRACT}

A 71-year-old male presented with Merkel cell carcinoma along with inguinal lymph node involvement (stage III). The patient was proposed for systemic treatment followed by inguinal lymphadenectomy and adjuvant radiotherapy. During the follow-up period, recurrences were documented (lymphatic and visceral) and were treated with salvage surgery and radiotherapy. On the fifth year of follow-up the patient was diagnosed with a metastasis in the right seminal vesicle and underwent stereotactic body radiation therapy. Two-years later, tumor recurrence in the right seminal vesicle was managed with salvage robotic assisted seminal vesiculectomy. Advanced stages of Merkel cell carcinoma have a poor outcome and salvage treatments should be tailored to each patient. A multidisciplinary approach was crucial in achieving successful outcomes. The patient is still recurrence free twenty-four months after surgery. To the best of our knowledge, this is the first publication reporting a seminal vesical Merkel cell metastasis.

Keywords: Carcinoma, Merkel Cell/therapy; Neoplasm Metastasis/surgery; Robotics; Seminal Vesicles/surgery

\section{RESUMO}

Doente do sexo masculino de 71 anos, com carcinoma de células de Merkel com metastização ganglionar inguinal (estádio III), submetido a terapêutica sistémica seguida de linfadenectomia inguinal e radioterapia adjuvante. Durante o seguimento, todas as recorrências foram tratadas com radioterapia ou cirurgia de salvação. Cinco anos após o diagnóstico inicial, o doente foi diagnosticado com uma metástase na vesícula seminal direita, tendo sido tratado com radioterapia estereotáxica corporal. Dois anos mais tarde, por nova recorrência do tumor na vesícula seminal direita, foi submetido a uma vesiculectomia seminal robótica de salvação. Estádios avançados do carcinoma de células de Merkel apresentam um prognóstico reservado e os tratamentos de salvação devem ser adaptados a cada doente. Uma abordagem multidisciplinar revelou-se crucial para o sucesso do caso. O doente encontra-se no vigésimo quarto mês de pós-operatório, sem evidência de recidiva de doença. Até à data, este é o primeiro caso descrito de metástase na vesícula seminal de carcinoma de células de Merkel.

Palavras-chave: Carcinoma de Célula de Merkel/tratamento; Metástase Neoplásica/cirurgia; Robótica; Vesículas Seminais/cirurgia

\section{INTRODUCTION}

Merkel cell carcinoma (MCC) is a rare skin tumor of neuro-endocrine origin with the propensity to metastasize systemically. Its first reference in literature was in 1972 as a 'trabecular carcinoma of the skin' by Toker. ${ }^{1}$ At diagnoses, around $26 \%$ of the patients have nodal involvement and $9 \%$ distant metastasis with five-year overall survival of $41.4 \%$ and $13.5 \%$, respectively. Occasionally, the diagnosis is made upon lymph node or distant metastasis without primary tumor found. ${ }^{2}$ Salvage metastasis surgery might benefit selected patients. To the best of our knowledge, there is no description in the literature of a seminal vesicle MCC metastasis. We report a case of salvage robotic-assisted seminal vesiculectomy using of daVinci® ${ }^{\circledR} \mathrm{Xi}$ system.

\section{CASE REPORT}

A 71-year-old male with a past medical history of hypertension, presented with right inguinal lymph node enlargement in 2011. Physical examination, laboratory and imaging work-up, including a contrast-enhanced computed tomography (CT) and a fluorodeoxyglucose (FDG)-positron emission tomography (PET), showed no other changes. An excisional biopsy of the inguinal lymph node was performed revealing a Merkel cell carcinoma (MCC) and, subsequently, the patient was treated with cisplatin and etoposide. Due to lymph node progression (retroperitoneal and inguinal), the patient underwent second-line treatment with topotecan with favourable response on FDG-PET, showing the remaining right inguinal nodes. Therefore, the patient underwent salvage right inguinal lymphadenectomy followed by adjuvant radiotherapy in 2012 . The patient remained asymptomatic without evidence of relapse until 2014 when he was diagnosed with a single left adrenal metastasis and underwent salvage surgery plus stereotactic body radiation therapy (SBRT). Later on, in 2016, FDG-PET detected a single metastasis in the right seminal vesicle (SV) which was treated with primary SBRT as it was considered to be the least iatrogenic treatment. In 2018, tumour recurrence in the right SV was noted (Fig. 1), without biopsy proven prostatic involvement. After an extensive discussion of the risks and small potentially oncological benefits of the salvage surgery, he underwent salvage robot-assisted bilateral seminal vesiculectomy in February 2019. First, the

\footnotetext{
1. Department of Urology. Hospital Beatriz Ângelo. Loures. Portugal.

2. Department of Urology. Hospital da Luz. Lisboa. Portugal.

$\triangle$ Autor correspondente: Luísa Jerónimo Alves. luisa.jeronimoaloves@gmail.com

Recebido/Received: 09/02/2021 - Aceite/Accepted: 04/06/2021 - Publicado Online/Published Online: 23/07/2021 - Publicado/Published: 01/06/2022 Copyright $\odot$ Ordem dos Médicos 2022
} 

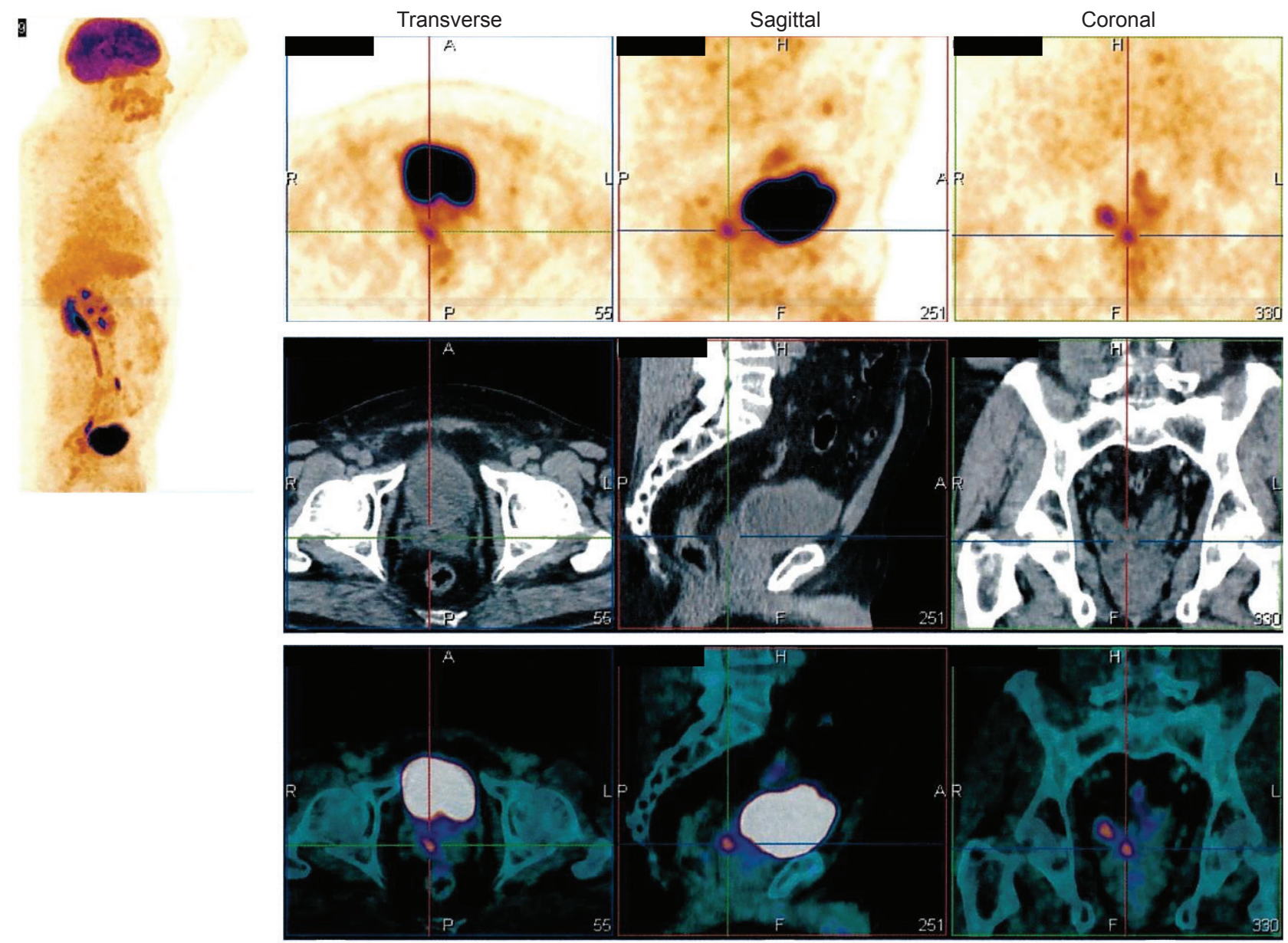

Figure 1 - FDG-PET-CT showing a recurrence in the right SV

peritoneum was incised to access the vas deferens and seminal vesicles. Afterwards, we proceeded with careful dissection of the medial and lateral attachments of SV up to the base of the prostate using selective coagulation. Vas deferens were clipped and sectioned. The post radiotherapy changes made the dissection challenging. The operative time was 100 minutes and blood loss $50 \mathrm{~mL}$. The histopathological examination of the surgical specimen (Fig. 2) revealed a MMC metastasis. The postoperative period was uneventful, and the patient was discharged on the day after surgery. Both FDG-PET and CT were performed at six, 12 and 24 months after surgery. The patient is on his twentyfourth post-operative month with no evidence of recurrence.

\section{DISCUSSION}

MCC is named based on is ultrastructural and immunophenotypic resemblance to sensory Merkel cells of the skin. An increasing incidence was noted which can be related with the ageing of the population. In 2013, the annual incidence in the USA was 0.7 cases per 100000 people. It is more frequent in males and tends to affect older people with $90 \%$ of patients being older than 50 -years. ${ }^{3} \mathrm{MMC}$ development is associated with Merkel cell polyomavirus (MCPyV) infection (present in $70 \%-100 \%$ of MCC specimens), immunosuppression and ultraviolet (UV) exposure. It presents classically as a rapid growing skin lesion in sun-exposed areas. ${ }^{4}$ However, around $15 \%$ of patients are diagnosed with lymph node involvement in the absence of identifiable cutaneous tumour. In these cases, it is assumed that the primary lesion has spontaneously regressed under immune surveillance which may explain the better outcomes in this group of patients. ${ }^{5}$ At diagnosis, around $65 \%$ of patients have localized disease while $28 \%$ present with nodal involvement and $8 \%$ with distant metastasis. The differential diagnosis between other poorly differentiated small roundcell neoplasms, such as small-cell carcinoma of the lung and small-cell melanoma, can be challenging and immunochemistry is necessary for a definitive diagnosis. ${ }^{4,6}$ According to the American Joint Committee on Cancer staging, nodal involvement is classified as a stage III disease, and it can be divided in IIIA and IIIB differentiating micro or macroscopic nodal disease. Our case is included in the stage IIIB category. ${ }^{5} \mathrm{MMC}$ is characterized by a high risk of relapse after initial surgical treatment and the best treatment approach is still controversial. In early stages (I and II) surgery with/without adjuvant RT should be offered. Bhatia et al reported improved survival associated with adjuvant RT in localized disease in a survival analysis of 6908 MCC cases. Although the survival benefit was not observed in stage III disease, adjuvant RT can decrease the risk of 


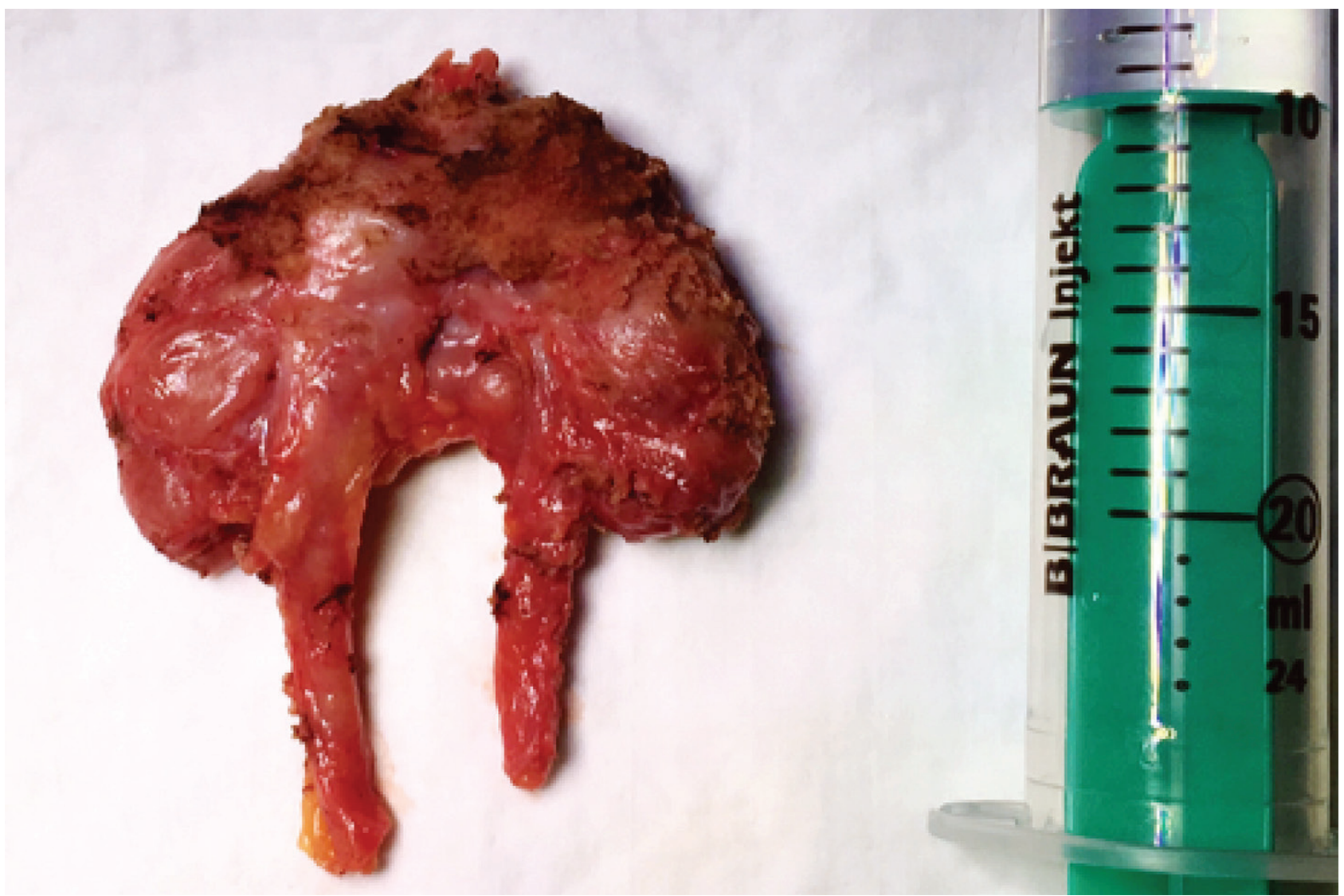

Figure 2 - Surgical specimen

recurrence after surgery. ${ }^{7}$ In our case, following the diagnosis of an advanced disease, the patient was proposed for systemic treatment. After completing two lines of chemotherapy, showing partial response, surgery and adjuvant RT were offered. During the follow-up period, visceral relapses were handled with surgery and SBRT. This case illustrates the unpredictability of MMC. To the best of our knowledge, we are not aware of another report in the literature of a seminal vesicle MMC metastasis. Taking into account our patient's clinical history and the favorable response after salvage treatment, a salvage robotic-assisted seminal vesiculectomy was proposed. In terms of prognosis, MCC is closely linked with the stage at presentation. Interestingly, recent data showed that stage III MCC with unknown primary lesion has better overall prognosis. A study by Tarantola et al reported an overall survival of $76 \%$ compared with $36 \%$ in stage IIIB MCC with known primary tumor. ${ }^{8} \mathrm{~A}$ higher mutation burden leading to increased neoantigen presentation could be one explanation for this difference. ${ }^{9}$

Due to its rarity, there is still limited data on the best approach in MCC and the literature is based on case reports and small retrospective series. Therefore, we feel that it is important to report a case with an unpredictable metastasis pattern and showing the feasibility of salvage seminal vesiculectomy. In this setting, robotic surgery could be an advantage to the challenging dissection of irradiated fibrotic planes. A multidisciplinary approach proved to be crucial to the successful outcomes of this particular case.

\section{AUTHORS CONTRIBUTION}

LJA: Drafting the paper. Conception and design of the work.

BG, KM: Data acquisition and review of the paper.

\section{PROTECTION OF HUMANS AND ANIMALS}

The authors declare that the procedures were followed according to the regulations established by the Clinical Research and Ethics Committee and to the Helsinki Declaration of the World Medical Association updated in 2013.

\section{DATA CONFIDENTIALITY}

The authors declare having followed the protocols in use at their working center regarding patients' data publication.

\section{PATIENT CONSENT}

Obtained.

\section{COMPETING INTERESTS}

None.

\section{FUNDING SOURCES}

This research did not receive any specific grant from funding agencies in the public, commercial, or not-for-profit sectors. 


\section{REFERENCES}

1. Toker C. Trabecular carcinoma of the skin. Arch Dermatol. 1972;105:10710.

2. Tai P, Park SY, Nghiem P. Staging, treatment and surveillance of Merkel cell carcinoma. Uptodate. [cited 2019 Apr 08]. Available from: https:// www.uptodate.com/contents/staging-treatment-and-surveillance-ofmerkel-cell-carcinoma.

3. Tai P, Nghiem P, Park SY. Pathogenesis, clinical features, and diagnosis of Merkel cell (neuroendocrine) carcinoma. Uptodate. [cited 2018 Aug 01]. Available from: https://www.uptodate.com/contents/pathogenesisclinical-features-and-diagnosis-of-merkel-cell-neuroendocrinecarcinoma.

4. Harms P, Harms K, Moore P, DeCaprio J, Nghiem P, Wong M, et al. The biology and treatment of Merkel cell carcinoma: current understanding and research priorities. Nat Rev. 2018;15:763-76.

5. Chen K, Papavasiliou P, Edwards K, Zhu F, Perlis C, Wu H, et al. A better prognosis for Merkel cell carcinoma of unknown primary origin. Am J
Surg. 2013;206:752-7

6. Haymerle G, Fochtmann A, Kunstfeld R, Pammer J, Erovic B. Management of Merkel cell carcinoma of unknown primary origin: the Vienna Medical School experience. Eur Arch Otorhinolaryngol. 2015;272:425-9.

7. Bhatia S, Storer B, Iyer J, Moschiri A, Parvathaneni U, Byrd D, et al. Adjuvant radiation therapy and chemotherapy in Merkel cell carcinoma: survival analyses of 6908 cases from the National Cancer Data Base. JNCI J Natl Cancer Inst. 2016;108:djw042.

8. Tarantola T, Vallow L, Halyard M, Weenig R, Warschaw K, Weaver A, et al. Unknown primary Merkel cell carcinoma: 23 new cases and a review. J Am Acad Dermatol. 2012;68:433-40.

9. Vandeven N, Lewis C, Makarov V, Riaz N, Paulson K, Hippe D, et al. Merkel cell carcinoma patients presenting without a primary lesion have elevated markers of immunity, higher tumour mutation burden and improved survival. Clin Cancer Res. 2018;24:963-71. 